$\infty$

ن.

ชิ

ㅇำ

ஸे

'ํำ

\title{
(slovensko-ruské paralely)
}

Martin Braxatoris

\author{
BRAXATORIS, M.: The Subject of Plurality of Worlds in the Poetry of \\ Enlightenment in Slovakia (Slovak-Russian Parallels) \\ SLOVENSKÁ LITERATÚRA 67, 2020, No. 3, p. $204-228$ \\ DOI: https://doi.org/10.31577/slovlit.2020.67.3.2
}

Key words: plurality of worlds, Augustín Doležal (1737 - 1802), Bohuslav Tablic (1769 - 1832), Mikhail Lomonosov (1711 - 1865)

The paper focuses on poetic texts which develop the subject of plurality of inhabited worlds. It continues on the research into the forms of this subject in the European literary tradition and in the new Latin-language tractate literature of Slovak provenance. The beginnings of thematizing plurality of worlds in Slovak poetry in vernacular language date back to the times when the influence of the Enlightenment ideas was at its peak or was still noticeable. The subject is present in a number of passages from Tragoedia by Augustín Doležal, which is undeniably only a fraction of the whole work, however, the idea of plurality of worlds has its significance in the system of teodicea, which was followed by this piece of writing. The subject was introduced into Slovak translation poetry by English poet Alexander Pope' s poem An Essay on Man, translated by Bohuslav Tablic. The paper is based on the assumption that Slovak literature was evolving in the area of poetic reflection in a way similar to those in other Eurepean literatures. It forms parallels with $18^{\text {th }}$ century Russian literary production based on closer interconnections between the works of A. Doležal and Mikhail V. Lomonosov. The conclusions show that the subject is represented by the works of significant Slovak poets from the late $18^{\text {th }}$ and early $19^{\text {th }}$ centuries. The fact that it is part of a more complex ideological system proves strong links with the European intellectual and literary context.

Klúčové slová: pluralita svetov, Augustín Doležal (1737 - 1802), Bohuslav Tablic (1769 - 1832), Michail Lomonosov (1711 - 1865) 

mer jeho knihy Hviezdoveda alebo životopis Krutohlava, čo na Zemi, okolo Mesiaca a Slnka skúsil a čo o obežniciach, vlasaticiach, pôvode a konci sveta vedel, ktorej rukopis dokončil v roku 1856, sa vytvára prostredníctvom naratívneho rámca dominantného odborného výkladu (let balónom vo vesmíre), podobne i dielo Augustína Doležala Pamětná celému světu tragoedia aneb veršovné vypsáni žalostného prvnich rodičů pádu (1791) sleduje na podklade, ktorý je v relevantnej miere fiktívny, ${ }^{3}$ ciele súvisiace s traktátovým žánrom. Tak v Doležalovom, ako aj v Reussovom prípade sa istá čast' takýchto ciel'ov týka polemík spätých s otázkou mimozemského života. V traktátovej literatúre slovenskej a širšie uhorskej proveniencie nie je reflexia týchto tém od 17. storočia ničím neobvyklým, ${ }^{4}$ Tragoedia Augustína Doležala je však v slovenskom kontexte výnimočná tým, že ide o poetické dielo vo vernakulárnom jazyku, ktoré sa svojím charakterom pohybuje na hranici fikcie a non-fikcie. ${ }^{5}$ Erika Brtáňová navzdory existujúcej tradícii chápania diela ako dialogizovaného traktátu ${ }^{6}$ uvažuje (na pozadí diferenciačných znakov románu, predovšetkým fiktívnosti a sústredenosti na čitatel'a) o jeho príslušnosti k románovému žánru, konkrétnejšie $\mathrm{k}$ (veršovanému) výchovnému románu v dialogizovanej forme. ${ }^{7}$ Vo vztahu k celej pamiatke argumentuje, že „domýšl'ané okolnosti nemali prekročit' rámec racionálneho úsudku, dôvtipu a ludskej skúsenosti, a rozhodne nemali protirečit' krestanskej vierouke“. ${ }^{8}$ Uzatvára, že „Doležalom explikovaný príbeh nemožno preto chápat' (ani s odstupom času) ako príbeh science-fiction“. 9 Dielo predtým spojila s vedeckou fantastikou Eva Fordinálová, ktorá v tejto súvislosti uvažovala o existencii sci-fi príbehov o minulosti a o väzbách medzi science

1 Napr. SRPOŇ, Vlado: Dr. Gustáv Maurícius Reuss: Prvý literárny fantasta Horného Uhorska? In: Interkom, 1993, č. 11 - 12. [cit. 2020-05-02]. Dostupné na: http://interkom.vecnost.cz/1993/19931116.htm 2 FERKO, Miloš: Prvý slovenský sci-fi román. In: Historická revue, roč. 7, 1996, č. 5, s. 33.

Slovenský syndikát autorov fantastiky v minulosti udel'oval cenu Gustáva Reussa o najlepšiu vedecko-fantastickú poviedku, pričom vitazné texty vychádzali v zborníku Krutohlav. Na námety tejto knihy dokonca vznikla rozhlasová hra (PAVLAC, Peter: Krutohlavova cesta na Mesiac, premiéra v rádiu Devín v roku 2014, dostupné na: https://www.rtvs.sk/radio/archiv/1365/54446) a prednedávnom aj divadelná hra (Hvizdna kapura alebo Dobrodružstvá Krutohlava, premiéra na festivale PegasCon 2017 v Prešove, dostupné na: youtu.be/tkc85FCPCKk

3 V tomto duchu sa nesie aj konštatovanie samotného autora: „Tento můj svatý román přináleží do počtu tech, v nichžto se vypravuje skutek opravdový, ale zavinutý jest do vymyšlených okolostojičností.“ DOLESCHALIUS, Augustinus: Pamětná celému světu Tragoedia... V Uherské Skalici : Vytištěná u Jozefa Antonina Škarnycla, 1791, s. [III]. Pozri aj BRTÁŇOVÁ, Erika: Na pomedzí traktátového a románového žánru. In: Slovenská literatúra, roč. 54, 2007, č. 5, s. 341.

4 Pozri ZAVARSKÝ, Svorad: Martin Sentiváni: Dissertatio cosmographica seu De mundi systemate / Sústava sveta. Kozmologická štúdia. In: Slavica Slovaca, roč. 46, 2011, č. 3, s. 109 - 110. KARABOVÁ, Katarína: Problematika mimozemských civilizácií z pohladu novolatinských spisov z oblasti fyziky. In: ŠKOVIERA, Daniel-SIPEKIOVÁ, Nicol (eds.): Sambucus IX. Trnava-Kraków : Filozofická fakulta Trnavskej univerzity v Trnave - Towarzystwo Słowaków w Polsce, 2013, s. 168 - 178.

5 Brtáňová, Na pomedzí traktátového a románového žánru, c. d., s. 341.

6 Prehl'ad názorov na žánrovú povahu Tragoedie podáva Brtáňová, Na pomedzí traktátového a románového žánru, c. d., s. 339 - 340 .

7 Tamže, s. 345.

8 Tamže. Pozri aj BRTÁŇOVÁ, Erika: Podoby idylickéhov Doležalovej Tragoedii. In: Slovenská literatúra, roč. 65,2018 , č. 1 , s. 28.

9 Brtáňová, Na pomedzí traktátového a románového žánru, c. d., s. 345. 
206 fiction a oblast'ou mýtov. ${ }^{10}$ Ako relevantná sa v danom smere môže javit' aktuálna rezignácia odborníkov na návrh funkčnej definície science fiction aj jednotnej definície celej fantastickej literatúry (science fiction, fantasy a i.). ${ }^{11}$ E. Fordinálová v monografii o Doležalovi interpretovala aj konkrétne pasáže diela venované téme plurality obývaných svetov. ${ }^{12}$ To, že ich necharakterizovala ako vedecko-fantastické, je v súlade s tým, že (pri akomkolvek žánrovom zaradení celej Tragoedie) tieto časti plnia persuazívnu funkciu (korelujúcu s traktátovou formou) a nie sú zamýšlané ako fantastické. Na spomínané verše upriamil pozornost' už Jaroslav Vlček, ktorý však nimi, paradoxne, podopieral svoju mienku, že „obnovujíci se naše poezie Tragoedií Doležalovou mnoho nezískala“.13

Ciel'om štúdie je zachytit širšie kontextové ukotvenie témy plurality obývaných svetov v slovenskej umeleckej literatúre. Doležal pritom nebol jediným slovenským autorom osvietenskej myšlienkovej orientácie, ktorý vo svojej básnickej tvorbe tematizoval pluralitu svetov. Ďalším spisovatel'om, ktorý uvádzal túto tému do slovenskej, i ked' prekladovej poézie, bol Bohuslav Tablic, ktorý v roku 1817 dokončil, po zásadnom prepracovaní však až v roku 1831 uverejnil preklad filozofickej básne Esej o člověku (1734) od anglického osvietenca Alexandra Popea, v ktorom sú prítomné aj pluralistické pasáže.

V zhode s predpokladom, že slovenská literatúra sa aj v oblasti poetickej reflexie vybranej témy vyvíjala podobne ako iné európske literatúry (pravda, s istými časovými, kvantitatívnymi a inými špecifikami), budeme sledovat' jej paralely s ruskou literárnou produkciou 18. storočia. Ďalším dôvodom na vytváranie analógií je užší súvis tvorby Augustína Doležala a Michaila Lomonosova, súvisiaci okrem iného s ich vzdelaním v leibnizovsko-wolffovských intenciách.

\section{Úvod}

Téma plurality svetov má v európskej literatúre a v dejinách myslenia bohatú tradíciu. Na jednej strane ide o rozmanitý súbor vedecko-fantastických, filozoficko-fantastických a fantasticko-satirických textov od autorov obdobia antiky (Lukianos zo Samosaty), renesancie (Ludovico Ariosto, Johannes Kepler, Francis Godwin, Thomas More, François Rabelais, Edmund Spenser, John Donne, Ben Jonson a i.), baroka (Savinien Cyrano de Bergerac, Charles Sorel a i.), osvietenstva (Jonathan Swift, François-Marie Arouet Voltaire, Rudolf Erich Raspe a i.) atd'. Čast' týchto textov obsahuje len určité prvky späté s ideou plurality svetov - ich funkcie v dielach sú rozmanité a ich interpretácii sa venuje množstvo literárnohistorických a iných vedeckých zdrojov. Pluralita obývaných svetov však predstavuje aj predmet seriózneho záujmu a postojov myslitel'ov či výskumníkov

10 FORDINÁLOVÁ, Eva: Stretnutie so starším pánom. Martin : Osveta, 1993, s. 9- 11.

11 Pracuje sa pritom s pojmami ako neostrá množina a prototyp, a tiež s členením fantastickosti na modus, žáner a formulu. Bližšie DĚDINOVÁ, Tereza: Úvodní slovo aneb Jak (ne)definovat fantastiku. In: DĚDINOVÁ, Tereza (ed.): Na rozhrani světu : fantastická literatura v mezioborovém zkoumání. Brno : Filozofická fakulta, Masarykova univerzita, 2016, s. 9 - 24 a tam uvedené zdroje.

12 Fordinálová, c. d., s. 186 - [191].

13 VLČEK, Jaroslav: Osvícenské Slovensko evangelické. In: Literatura česká devatenáctého století. Díl první... Praha : Jan Laichter, 1902, s. 606. 
od staroveku po súčasnost'. ${ }^{14}$ Súvisiace myšlienky v pozitívnom zmysle rozvíja- 207 li antickí filozofi (Demokritos z Abdér, Leukippos z Milétu, Epikuros zo Samu, Lucretius Carus, Plutarchos a i.), negatívne sa voči nim vymedzil najmä Aristoteles. V stredoveku (osobitne pod vplyvom názorov Tomáša Akvinského) prevládli stanoviská nadväzujúce na aristotelovskú a ptolemaiovskú kozmológiu, voči ktorým však existovala pluralistická opozícia vychádzajúca z dôsledkov dogmy o Božej všemohúcnosti. Rozpory vyvrcholili v roku 1277, ked' Parížska univerzita zakázala vyučovat' 219 téz, ktoré komisia pod vedením parížskeho biskupa Étiennea Tempiera odsúdila ako herézy; zoznam obsahoval aj popieranie možnosti existencie viacerých svetov. ${ }^{15} \mathrm{~V}$ univerzitných centrách v Paríži a v Oxforde sa stanoviská pripúštajúce pluralitu svetov rozvíjali aj v poslednej tretine 13. storočia. ${ }^{16} \mathrm{~V} 14$. storočí, v súvislosti s témou nekonečnej Božej moci, vyjadrili pluralistické náhl'ady William z Ockhamu, Jean Buridan či Mikuláš z Oresme a v 15. storočí Mikuláš Kuzánsky, ${ }^{17}$ ktorý rozvijjal myšlienku o vesmíre bez centra a bez hraníc. Východiskom d'alšieho oživenia pluralistických ideí bolo to, že nad geocentristickou paradigmou vesmíru začal dominovat' heliocentristický model vesmíru, ${ }^{18}$ o čo sa osobitne zaslúžil Mikuláš Kopernik a súdobé astronomické objavy. Priekopnícku rolu v úvahách o nekonečnom vesmíre s množstvom hviezd podobných nášmu Slnku a s množstvom planetárnych systémov zohral anglický bádatel' Thomas Digges a o čosi neskôr Giordano Bruno, ktorého názory sa formovali aj pod vplyvom Mikuláša Kuzánskeho. Zoznam d'alších významných vedcov, filozofov a literátov, ktorí v rôznych podobách prezentovali pluralistické stanoviská, by bol vel'mi dlhý a obsahoval by mená rozmanitých osobností ako Johannes Kepler, Galileo Galilei, Pierre Gassendi, John Wilkins, Christiaan Huygens, Bernard Le Bovier de Fontenelle, John Locke, George Berkeley, Gottfried Leibniz, Christian Wolff, Michail Lomonosov, Immanuel Kant, Barthold Heinrich Brockes, Albrecht von Haller, Cotton Mather, Pierre Louis Maupertuis, François-Marie Arouet Voltaire, Edward Young, Alexander Pope a i. K dejinám myslenia o tejto otázke existuje rozsiahla bibliografia, zahŕňajúca aj mimoriadne kvalitné vedecké syntézy. ${ }^{19}$ Téma má svoje pevné miesto v početných monografiách

14 Vo vztahu k súčasnosti výberovo spomeňme napr. štúdie v cambridgeskom časopise International Journal of Astrobiology či transdisciplinárnu kolektívnu monografiu REGIS, Edward Jr. (ed.): Extraterrestrials... Cambridge-London-New York-New Rochelle-Melbourne-Sydney : Cambridge University Press, 1987. 15 DICK, Steven J.: Plurality of Words: The Extraterrestrial Life Debate from Democritus to Kant. Cambridge : Cambridge University Press, 1984, s. 28; GRANT, Edward:Planets, Stars and Orbs. The Medieval Cosmos, 1200 - 1687. Cambridge : Cambridge University Press, 1996, s. 53 - 55; THJISSEN, Hans: Condemnation of 1277. In:ZALTA, Edward N. (ed.): Stanford Encyclopedia of Philosophy. Stanford : Metaphysics Research Lab, CSLI, Stanford University, 2018. [2020-02-05]. Dostupné na: https://plato.stanford.edu/archives/ win2018/entries/condemnation/

16 Dick, c. d., s. 28 - 29; Grant, c. d., s. 155 a n.

17 ECO, Umberto: Inventing the Enemy and Other Occasional Writings. Translated from the Italian by Richard Dixon. Boston - New York : Houghton Mifflin Harcourt, 2012, s. 152; podrobnejšie Dick, c. d., s. 29 - 42.

18 Popri nich existoval aj geo-heliocentristický model, ktorý v druhej polovici 16. storočia navrhol Tycho Brahe.

19 Osobitne spomeňme monografie Dick, c. d. (prvé vydanie 1982); CROWE, Michael J.: The Extraterrestrial Life Debate 1750 - 1900: The Idea of a Plurality of Worlds from Kant to Lowell. Cambridge : Cambridge University Press, 1988. 
208 venovaných kozmologickým koncepciám na širokej dejinnej ploche ${ }^{20} \mathrm{v}$ jednotlivých historických obdobiach ${ }^{21}$ či v tvorbe konkrétnych autorov, ${ }^{22}$ nehovoriac už o kvante vedeckých článkov a štúdií v časopisoch, zborníkoch a pod.

Z hl'adiska zamerania predloženej štúdie je podstatné, že téma plurality svetov sa reflektovala aj v uhorskom a slovenskom kontexte, osobitne v novolatinskej traktátovej literatúre. Svorad Zavarský označuje za najvýstižnejší uhorský prameň obsahujúci prehl'ad antických autorov argumentujúcich v prospech nekonečného množstva svetov text Petra Pázmaňa, ktorý sem radil Anaximandra, Anaximena, Diogena, Epikura a Anaxarcha; iní autori k nim bežne pridávali aj Demokrita. ${ }^{23}$ Pázmaňov text tiež sprostredkúva znalost' základných prameňov v prospech jedinečnosti sveta (Aristoteles, komentátori z Coimbry, Bonamicus). ${ }^{24}$ Argumenty proti pluralite svetov uvádza (v nadväznosti na Bibliu, Tomáša Akvinského a Tycha Braheho) i slovenský filozof Martin Sentiváni v kozmologickej štúdii Sústava sveta (1678). ${ }^{25}$ Profesor Trnavskej univerzity Andrej Jaslinský v spise Druhá čast'náuky o fyzike alebo čiastková fyzika (1756) predkladá podla Kataríny Karabovej kriticky podloženú argumentáciu pre a proti existencii obyvatel'ov iných nebeských telies, pričom odkazuje na pluralistické názory pytagorejcov, Pseudo-Plutarcha a Xanofana (podl'a Ciceróna), na názory neskorších autorov vrátane Mikuláša Kuzánskeho či Antona Maria z Reutte, a d'alej aj na mienku Christiana Wolffa. ${ }^{26}$ Podobne Anton Revický, d'alší profesor Trnavskej univerzity, v diele Základy prírodnej filozofie druhá čast' alebo čiastková fyzika (1758) začína prehl'ad súvisiacich autorov pytagorejcami a Xerofanom (podl'a Ciceróna), a pokračuje totožnými západnými filozofmi ako Jaslinský; bližšie si pritom všíma názory Christiaana Huygensa a Christiana Wolffa. ${ }^{27}$

Ak sa zameriame na kontext ruskej literatúry, myšlienky o pluralite svetov doň prenikali v období osvietenstva, rovnako prostredníctvom antických autorov. Lucretiovu hexametrickú, obsahom i názvom epikurejskú poému O prirodzenosti vecí vysoko hodnotili autori ako Michail Lomonosov a Alexander Radiščev. ${ }^{28}$ Pri etablovaní pluralistických stanovísk zohrali klúčovú úlohu Rozhovory o pluralite svetov Bernarda le Boviera de Fontenelle (1686). Fontenelle nadviazal na Descartovu teóriu o kozmických víroch (zhlukoch pohybujúcich sa častíc vytvárajúcich hviezdy a planetárne systémy), ktorých počet rozšíril na nekonečný, a oprel o to svoju tézu o osídlení Mesiaca, Venuše, Merkúra, Marsu, Jupitera, Saturnu a objektov v iných planetárnych systémoch. Rozhovory o pluralite svetov

20 HARRISON, Edward Robert: Darkness at Night: A Riddle of the Universe. Cambridge - Massachusetts London : Harvard University Press, 1987; HARRISON, Edward: Masks of the Universe. Changing Ideas on the Nature of the Cosmos. Cambridge : Cambridge University Press, 2003.

21 Napr. Grant, c. d. (prvé vydanie 1994).

22 SZENDY, Peter: Kant in the Land of Extraterrestrials: Cosmopolitical Philosofictions. Translated by Will Bishop. New York : Fordham University Press, 2013 (francúzsky originál 2011).

23 Zavarský, c. d., s. 109.

24 Tamže.

25 Dissertatio cosmographica seu De mundi systemate. Zodpovedajúce pasáže v latinskom origináli i slovenskom preklade Zavarský, c. d., s. 18-25.

26 Karabová, c. d., s. $171-172$.

27 Tamže, s. $173-174$.

28 Neskôr s nadšením aj Alexander Gercen. TRONSKIJ, Iosif Moisejevič: Dějiny antické literatury. II. díl, Řimská literatura. Praha : Nakladatelství Československé akademie věd, 1956, s. 115. 
mali v ruskej literatúre 18. -19. storočia značný ohlas, o čom svedčia kvalitné pre- 209 klady Antiocha Kantemira (1740) a Ivana Butovského (1821). Kantemirov preklad vyvolal autorom očakávanú ${ }^{29}$ ostrú reakciu konzervatívnych častí ruských intelektuálnych elít. ${ }^{30}$ Dokonca ešte viac než dvanást' rokov po Kantemirovej smrti, na prelome rokov 1756 a 1757, žiadala Najsvätejšia synoda Ruskej cirkvi cárovnú Alžbetu Petrovnu o konfiškáciu výtlačkov tejto knihy. ${ }^{31}$ V roku 1761 dal Michail Lomonosov $^{32}$ pokyn akademickej typografii na jej druhé vydanie. V roku 1802 ju Cárska akadémia vied vydala tretíkrát. Na Fontenellovo dielo nadväzovali ruskí básnici ako Michail Lomonosov, Gavril Deržavin, Alexander Sumarokov a Michail Cheraskov, neskôr bolo populárne v prostredí predstavitel'ov ruských elít, napr. medzi dekabristami a u Alexandra Puškina. ${ }^{33}$ Za zmienku azda stojí skutočnost', že v prvej tretine 19. storočia evidoval Kantemirov preklad aj Pavol Jozef Šafárik. ${ }^{34}$ V slovenskom literárnom kontexte nadväzuje na Fontenellovo dielo Gustáv Reuss, ktorý ním začiatkom druhej polovice 19. storočia končí prehlad názorov svojich predchodcov na obývanost' známych planét (Christiaan Huygens, Athanasius Kircher, Bernard le Bovier de Fontenelle). ${ }^{35}$

$\mathrm{Z}$ autorov, ktorí ovplyvnili reflexiu plurality obývaných svetov v slovenskej i ruskej poézii, treba zvlášt' spomenút Alexandra Popea. Mimoriadny význam pre oba literárne kontexty však majú nemeckí filozofi Gottfried Leibniz a Christian Wolff, ktorí predstavovali ideový zdroj slovenského (Augustín Doležal) a ruského (Michail Lomonosov) pluralizmu. Leibnizov záujem o myšlienku možných svetov možno východiskovo sledovat' až po rukopis napísaný v roku 1676 a jeho korešpondenciu s Johannom Bernoulliom, no svoje názory v tomto smere prvýkrát publikoval až v diele Théodicée (1710). Formuloval ich síce už skôr $\mathrm{v}$ dialogickom spise Nové eseje o ludskom poznaní, ktorý dokončil v roku 1704, no ked'že vyšiel až v roku 1765, k verejnosti sa dostali neskôr. ${ }^{36}$ Jedným z prvých zástancov jeho systému bol Christian Wolff, ktorý v mnohých svojich spisoch potvrdzuje aj svoje pluralistické stanoviská. ${ }^{37}$ Leibnizova podpora pluralizmu bola rozhodujúca vo Wolffových kompendiách, ktoré boli najčítanejšie z diel jeho významných nasledovníkov. ${ }^{38}$

29 BOBINE, Georgij: Filosofskije vozzrenija Antiocha Kantemira. Kišiňov : Štiinca, 1981, s. 51.

30 Pozri napr. ŠIŠKIN, I[akinf Ivanovič]: Michail Abramov-odin iz protivnikov Petrovskoj reformy. In: Nevskij sbornik (učebno-literaturnyj). S. Peterburg : Izdanie Vl. Kuročkina, 1867, s. 424.

31 Jejžiadost' zrejme ostala bez reálnych konzekvencií, ked'že kniha bola v tom čase takmer rozpredaná. Bližšie KONDAKOV, Ivan Petrovič (ed.): Svodnyj katalog knig graždanskoj pečati XVIII veka. 1725 - 1800. Tom 3. R-Ja. Moskva : Kniga, 1966, s. 313.

32 KULIKOVSKIJ, Petr Grigorievič: M. V. Lomonosov - astronom i astrofizik. Izd- 2-je. Moskva : Gos. izd-vo fiz.-mat. lit., 1961, s. 50.

33 MOMDŽIAN, Chačik Nišanovič: Francuzskoje prosveščenije XVIII veka... Moskva: Mysl', 1983, s. 49. Puškin dokonca uvádza Fontenella medzi autormi, ktorých diela čítal Eugen Onegin (8, XXXXV). PUŠKIN, Alexander/Alexandr Sergejevič: Jevgenij Onegin.../Eugen Onegin... Prel. Ján Štrasser. Bratislava : Petrus, 2002.

34 SCHAFFARIK, Paul Joseph: Geschichte der slawischen Sprache und Literatur nach allen Mundarten.

Ofen : mit Kön. Ung. Universitäts-Schriften, 1826, s. 163.

35 REUSS, Gustáv: Hviezdoveda. Bratislava : Tatran, 1984, s. 145 - 152.

36 Crowe, c. d., s. 28.

37 Tamže, s. 30.

38 Bližšie tamže, s. 140. 
Leibnizove a Wolffove idey ovplyvnili Augustína Doležala, ${ }^{39}$ ktorý v rozovho diela Théodicée. ${ }^{42}$ Pre porovnanie, Michaila Lomonosova ovplyvnil z hl'adiska uvažovania o pluralite svetov (popri Fontenellovi) Ch. Wolff, ${ }^{43}$ ktorý bol jeho pedagógom na marburskej univerzite v rokoch 1736 - 1739 .

\section{Kozmológia Augustína Doležala}

Koncepcia Augustína Doležala sa zakladá na kontraste konečného univerza (světa) a ničoty (Ničeho), ktorá je za jeho hranicami; ${ }^{44}$ čokolvek iné za rozmedzím sveta by sa stalo jeho súčast'ou. ${ }^{45}$ Svet charakterizuje Doležal ako celok zložený z konečných podstát, ${ }^{46}$ ktoré sú približnými ekvivalentmi monád v Leibnizovej či Wolffovej filozofii. ${ }^{47}$ I ked' ničote nemožno podl'a neho prisúdit' žiadne podstatné vlastnosti, ${ }^{48}$ prostredníctvom postavy Séta kladie otázku, či pred stvorením sveta existoval len Boh a ničota okolo neho. ${ }^{49}$ Ontologický status „ničoho“ a súvisiaca koexistenčná otázka sa dnes nejavia ako problematické, ${ }^{50} \mathrm{v}$ pozadí je však otázka, či pred stvorením nášho sveta možno pripustit' existenciu iných

39 Bližšie MÜNZ, Teodor: Filozofia slovenského osvietenstva. Bratislava : Slovenská akadémia vied, 1961; MÜNZ, Teodor: Osvietenská filozofia. In: Dejiny filozofického myslenia na Slovensku I. Bratislava : VEDA, 1987, s. 218 - 220. Novšie sa vplyvov týchto filozofov na Doležalove filozofické názory dotýka GLUCHMAN, Vasil: The Origin of Evil and Benefits of Sin. In: HARRIS, Harriet A. (ed.): God, Goodness and Philosophy. London - New York: Routledge Taylor \& Francis Group, 2016, s. 209 - 216.

40 BRTÁŇ, Rudo: Priprameňoch slovenskej obrodeneckej literatúry. Bratislava:Vydavatel'stvo Slovenskej akadémie vied, 1970, s. 243.

41 Tamže, s. 243 - 244; pozri aj Fordinálová, c. d., s. 17.

42 Gluchman, c. d., s. 211.

43 Porov. Crowe, c. d., s. 159.

44 Doleschalius, c. d., s. $169-170$.

45 „Ved' kdyby za světem něco ješte bylo, to by se svou vazbou i světa chytilo!“ Doleschalius, c. d., s. 170.

46 Doleschalius, c. d., s. 166, 170.

47 K špecifikám Doležalovej metafyziky pozri Münz, Osvietenská filozofia, c. d., s. 218 - 220; Münz, Filozofia slovenského osvietenstva, c. d., s. $208-211$.

48 „... žádné ni možnosti ni co skutečného.“ Doleschalius, c. d., s. 171.

49 „Nuž, okolo něho též Nic jen bývalo, / prv, nežli stvoření jaké jej ctívalo?“ Doleschalius, c. d., s. 172.

50 Fakt, že podmnožinou množiny \{Boh\} s kardinálnym číslom 1 je aj prázdna množina $\{s$ kardinálnym číslom 0 , nerozširuje ontológiu pred stvorením na množinu $\{$ Boh, 0$\}$ s kardinálnym číslom 2. 
entít ako Boha (prázdneho priestoru ${ }^{51}$ či sveta iných bytostí). ${ }^{52}$ Doležal na nastolenú otázku odpovedá, že pred stvorením bol Boh potešením sám sebe. ${ }^{53} \mathrm{Ta}-$ káto odpoved' sa javí ako prirodzená, ked'že Boh je v jeho monádológii jedinou podstatou, ktorá nie je konečná a stvorená. ${ }^{54}$

Do sveta (univerza) ako konečného súboru konečných stvorených podstát Doležal umiestňuje tisíce nebeských objektov a zdôrazňuje ich rozmanitost':

\author{
„Obloha, kterou ty nad sebou spatřuješ, \\ a, jak pravišs, dobře také považuješ, \\ nic jiného neni než povětř́ pouhé, \\ po tom celém světě široké a dlouhé; \\ (...) \\ $V$ tom tedy povětří, co v nějakém placi, \\ ukázal nám Pán Bůh svou di̊stojnou práci; \\ porozkládal po něm slunce, hvězdy, Měsíc, \\ čehož všeho jestit'do několik tisíc: \\ Ty hvězdy nejsou, jak ty mysliś, jednaké! \\ Jsou ony v natúre svojéj všelijaké; \\ jedny jsou jen světlo samé, čisté, púhé, \\ jiné zas nečisté, tmavé, kalné, tuhé. \\ Svètlé jsou takové, prám jak toto slunce, \\ tmavé jako Měsíc v své po nebi chůzce. \\ Měsíc pak jest taký, prám jak země táto, \\ jako roli, voda, skála, hory, bláto."55
}

Prostredníctvom Adama vyjadruje presvedčenie, že aj mimo Zeme existuje život:
„Jestli tedy Pán Bůh nás na tou zem vsadil, jakby, prosím, skutkům svým slavně poradil, kdyby ty podobné ćástky prázdné stály
a tvoru živému mistečka neprály?"56

\footnotetext{
51 Napr. Mikulášz Oresme a Pierre Gassendi zastávali myšlienku o preexistencii prázdneho priestoru, zatial' čo Jean Buridan, Tomáš Akvinský i Étienne Tempier ju popierali (BELLIS, Delphine: Imaginary Spaces and Cosmological Issues in Gassendi's Philosophy. In: BAKKER, Frederik-BELLIS, Delphine-PALMERINO, Carla Rita (eds.): Space, Imagination, and the Cosmos, from Antiquity to the Early Modern Period. Dordrecht: Springer, 2018, s. 241 -242). Otázka kozmogonickej roly prázdneho priestoru má pritom antické korene. 52 Niektorí autori pripúštali úvahu, že pred stvorením viditel'ného sveta (o ktorom hovorí Genezis 1,1) existoval svet anjelov. Z cirkevných otcov Bazil Vel'ký v tomto smere hovorí o stave spätom s duchovným svetlom a anjelskými bytostami (Hexaemeron, Homilia I, 5; II, 5. BAZIL VEL'KÝ, Sv.: Listy II. (r. 375 - 378), Hexaémeron. Preložil Daniel Škoviera. Prešov: Náboženské vydavatel'stvo Petra, 2002, s. 185, 199). Takejto možnosti sa v krátkosti dotýka aj Doležal, aby ju následne zavrhol: „Okolek tam bývá, kdejaké prostranství, / kde Pán kromě sebe má též i poddanství. / Ale před stvořením ted' světa našeho / Bůh neměl žádného tvoru stvořeného. / A tak tu nemůžeš ani to mysliti, / coby bylo mohlo vůkol Boha býti.“ Doleschalius, c. d., s. 172. 53 Doleschalius, c. d., s. 172.

54 Tamže; pozri i Münz, Filozofia slovenského osvietenstva, c. d., s. 210; Münz, Osvietenská filozofia, c. d., s. 219.

55 Doleschalius, c. d., s. 226-227.

56 Tamže, s. 227.
} 
"Jestli na té zemi i červíček leze, Prázdné-ližv Měsíci, pověz, budou meze?

Neni-liž tam někdo rozumný bydlitel, kterýzná, že Pánem jeho jest Stvoritel..."57

Nepredpokladá pritom len osídlenie Mesiaca, ale aj d'alších planét slnečnej sústavy a iných planetárnych systémov. Zdôvodňuje „celkom v súlade s osvietenskými názormi, že aj iné planéty sú obývané rozumnými bytostami“. 58 Jeho predpoklad súvisí so stratou výnimočného postavenia Zeme aj so stratou exkluzivity Slnka medzi inými hviezdami:

„Co sem ti povědel nyní o Měsíci, to ti můž byt jednou v svètě celém svicí. Toto naše slunce, ač se ti snad nezdá, nic jiného není, než pravdivá hvězda.

(...)

Okolo té hvězdy nám takto nejbližši

během svojím běži planéty i jinší." 59

„Vidišs, Séte, kolik, co slunce, jestit'hvězd, tolik zvláštnich světů $i$ v tom světě jest! Každá taká hvězda má svoje planety, které, když vidime, zovou se komety."60

Názor na obývanost' Mesiaca pritom Doležal nevydáva za „neomylnú pravdu“, ${ }^{61}$ ale prezentuje ho ako rozumom podloženú tézu, z ktorej plynú d'alšie otázky.

„Já nic nevymýšlím! Držím se moudrosti, kterou mi Bůh můj dal z lásky a milosti. $V$ Měsíci sem nebyl, to jest pravda samá! Zdaž jen to víme, co šlapáme nohama? ${ }^{62}$ „Já sem nepověděl, že já to jistě vím! Ale však rozumně a gruntovně pravím..."63 
Predpoklad existencie rozumných živých bytostí mimo Zeme nastoluje z hl'adiska krestanského svetonázoru otázky, ktoré v našej dobe zhrnul Umberto Eco: „Nekonečnost' svetov vrhá pochybnosti na unikátnost' spasenia: Adamov hriech a Kristovo utrpenie sú bud'bezvýznamnou epizódou, relevantnou len vo vzt'ahu k nášmu svetu, nie však k iným Božím dielam, alebo sa Golgota musí opakovat' nespočetnekrát na nekonečnom množstve planét, čo ruší majestátnu jedinečnost' obety Syna človeka." ${ }^{64} \mathrm{O}$ súvisiacich otázkach uvažuje (na základe akceptácie Descartovej teórie vírov a Fontenellových názorov) abbé Jean Terrasson v práci Pojednanie o nekonečnom stvorení (tlačou vydaná v roku 1769, no už niekol'ko rokov predtým koloval jej rukopis). Dospieva k názoru, že sa Boh vtelil aj na planétach bez hriechu, ked'že bezhriešne bytosti si zaslúžili takúto vel'kú čest', že na planétach, do ktorých nevstúpil hriech, sa Slovo rodí z rovnakého počatia ako ostatní ludia a že na nich Kristus plní úlohu učitel'a, zatial'čo na Zemi má rolu učitel'a aj spasitela. ${ }^{65}$

Osobitnú rolu má tento problém v Leibnizovej filozofii, podl'a ktorej Boh vybral a stvoril najlepší zo všetkých možných svetov (t. j. univerz). ${ }^{66}$ Stanovisko, že náš svet je najlepší zo všetkých možných svetov, rozvíja vo svojej Tragoedii aj Augustín Doležal. ${ }^{67}$ Leibniz v rámci apológie Boha vo vztahu k existencii zla tvrdí, že ,,je možné, že všetky slnká sú obývané iba požehnanými stvoreniami“ a navodzuje predstavu, že za ich hranicami môže byt' čosi ako „oceán, do ktorého tečú rieky všetkých požehnaných stvorení, ked' dosiahnu svoju dokonalost' v systéme hviezd“. ${ }^{68}$ Uvažuje o možnosti, že len naša Zem ,je takmer stratená v ničote“, a tak „možno všetky sú takmer ničím v porovnaní s dobrými vecami, ktoré sú vo svete“ ${ }^{69}$ Michael J. Crowe zhŕňa, že naša planéta je podl'a Leibniza najhoršia v najlepšom možnom vesmíre, pričom však Adamov pád bol v istom zmysle ,štastným hriechom“, pretože viedol ku Kristovmu vteleniu a k vykúpeniu. ${ }^{70}$ Túto tézu o zmysle dopustenia hriechu rozvíja (popri argumente o rešpektovaní slobodnej vôle a o dôsledku rozmanitosti) aj Doležal. ${ }^{71}$

Leibniz v Théodicée uvažuje, že vesmír obsahuje „nekonečný počet zemegúl', takých významných a významnejších ako tá naša, ktoré majú také isté právo mat' rozumných obyvatel'ov, hoci to vôbec neznamená, že sú to ludia“".72 V dialogickom spise Nové eseje o l'udskom poznaní uvažuje o situácii, že by z Mesiaca prišiel niekto ako Gonsales (cestovatel' po vesmíre z Godwinovho Človeka na mesiaci). Načrtáva teoretickú otázku, či by obyvatelia Mesiaca - ako rozumné, človeku podobné živočíchy (odkazuje tu na názor Christiaana Huygensa), ktoré nie sú potomkami Adama - mali byt' pokrstené a obrátené ku krestanskej viere,

64 Eco, c. d., s. 152, pracovný preklad M. B.

65 Crowe, c. d., s. 134- 135.

66 Tamže, s. 28, 29.

67 Doleschalius, c. d., s. 183 - 185 (\$ 152: Svět náš jest nejlepší!). Potom akoby sa však stierala hranica medzi svetom ako univerzom a Zemou, na ktorú sa obmedzujú d'alšie reflexie o dopustení hriechu (tamže, s. 185 a n.).

68 LEIBNIZ, Gottfried Wilhelm: Theodicy... Translator E. M. Guggard, editor Austin M. Farrer. New York : Cosimo, 2009, s. 135, pracovný preklad M. B.

69 Tamže, s. 135, pracovný preklad M. B. Pozri aj Crowe, c. d., s. 29.

70 Crowe, c. d., s. 29.

71 Doleschalius, c. d., s. 199 - 201; zostávajúce dva argumenty tamže, s. 198 - 199, 201 - 203.

72 Leibniz, c. d., s. 135. 
214 resp. či by l'udia mali šírit' vieru v oblastiach mimo našej planéty. Túto cestu označuje za najnebezpečnejšiu a pochybuje o tom, že by sa im mohla udel'ovat platpochybnu. ${ }^{3}$ Otázke absencie genealogickej väzby obyvatelov Mesiaca na Adama sa pritom venoval aj Fontenelle, ktorý argumentuje, že nielenže nie sú priamymi potomkami Adama, ale nie sú ani lud'mi. ${ }^{74}$ Vyhýba sa tu rozporu s biblicky fundovanou tézou, že všetci ludia sú potomkami Adama a Evy (Genezis 3,20; Skutky 17,26). Na hroziacu kontradikciu obracia pozornost' aj Fontelellov ruský prekladatel' Antioch Kantemir: „keby na Mesiaci boli ludia, bolo by nepravdivé Sväté písmo, ktoré odvodzuje celý ludský rod od Adama."75 Súvisiaci argument proti pluralizmu je pritom starý a vyskytuje sa v množstve prameňov, napr. v uhorskom a slovenskom kontexte ho uvádza Martin Sentiváni v kozmologickej štúdii Sústava sveta $(1678) .{ }^{76}$

V ruskom literárnom kontexte nastolil podobné otázky ako Leibniz Wolffov žiak Michail Lomonosov. V roku 1761 (v ktorom vyšlo aj druhé vydanie Kantemirovho prekladu Fontenellovej knihy) opísal a vysvetlil optický efekt pri prechode Venuše spätý s existenciou jej atmosféry. ${ }^{77} \mathrm{~V}$ Dodatku opisu tohto javu píše:

„Niektorí sa pýtajú; ak sú reku na planétach l'udia, nám podobni, tak akej sú viery? Je im ohlásené Evanjelium? Sú pokrstení na vieru Kristovu? Týmto sa dáva odpoved'otázkou. Vo vel'kých južných zemiach, ktorých brehy v terajšich časoch používajú takmer len moreplavci, tamojší obyvatelia, tiež aj obyvatelia viných neznámych zemiach, l'udia vzhl'adom, jazykom a všetkým správaním odlišní, sú akej viery? Ak o tom niekto chce vediet', alebo ich obrátit' a pokrstit', ten nech tam podl'a slova Evanjelia (,Neberte si do opaskov ani zlato, ani striebro, ani peniaze; ani kapsu na cestu si neberte ani dvoje šiat, ani obuv, ani palicu' ${ }^{6}{ }^{78}$ ide. Len však aby jeho práca nebola zbytočná. Možno, že tamojši obyvatelia v Adamovi nezhrešili a preto všetky toho dôsledky nie sú potrebné. ,Je mnoho ciest $k$ spáse. Na nebesiach je mnoho príbytkov. "“79

Druhá čast' záverečného pseudocitátu predstavuje parafrázu Evanjelia podla Jána 14,2 („V dome môjho Otca je mnoho príbytkov“), ktorá sa však ocitá v kontexte myšlienok o pluralite svetov. Stojí za zmienku, že v zásade podobne, i ked' vo vážnom teologickom duchu a bez náznakov ironizovania, vnímal v 19. storočí možnost' bezhriešnosti obyvatel'ov iných nebeských objektov ruský svätec Teofan Zatvorník. ${ }^{80}$

73 Crowe, c. d., s. 29.

74 FONTENELLE, Bernard Le Bovier de: Entretiens sur la pluralité des mondes... Nouvelle édition. Parisis : e l'imprimerie d'Aug. Delalain, 1822, s. vij - viij.

75 FONTENELL, Bernar Le Bovie de: Razgovory o množestve mirov... V Sanktpeterburge : Pri Imperatorskoj Akademii Nauk, 1740, s. XIII, pracovný preklad M. B.

76 Zodpovedajúce pasáže v latinskom origináli i slovenskom preklade Zavarský, c. d., s. 22 - 24.

77 Bližšie Kulikovskij, c. d., s. 43 - 49.

78 Evanjelium podla Matúša 10,9-10.

79 LOMONOSOV, Michail Vasilievič: Polnoje sobranije sočinenij. V11 tomach. Tom 4. Moskva - Leningrad : Izdatel'stvo Akademii nauk SSSR, 1955, s. 374 - 375, pracovný preklad M. B.

80 FEOFAN ZATVORNIK, sviatitel': Pravoslavie i nauka. Rukovodstvennaja kniga izrečenij i poučenij. Moskva : Danilovskij Blagovestnik, 2005, s. 611 - 617. Obsiahle citácie uvádzame v štúdii BRAXATORIS, Martin: Ideja množestva mirov... In: Devin : Al'manach... Moskva : MIK, roč. 5, 2019, č. 2, s. 88 - 89. 
Aj Doležal pripúšta možnost', že obyvatelia Mesiaca a iných planét nie sú zatažení prvotným hriechom:

„A musel-liž by on v Měsíci hřešiti proto, že sme se my dali poškvrniti?"

Toto stanovisko rozvíja na neskoršom mieste:

„A tam, bez pochyby, živé jest v svatosti, aniž jest zšpatněno nejakou hř́šností. Nezlořečil tam Bůh zemi, jako naši, tam se požehnání Boži samo vznáši! Nemáš tam bedáře, jak my neboráci, tam páni jsou jistě, my sme jen žebráci!"82

Podobne aj pri otázke osídlenia iných planét uvádza:

„Jak ti jest to predce v srdci tvojém lito, že jest svět pošpatěn celý takovýto! Jakbychom my, na téjiž proklaté zemi, byli jen Magnates mezi tvory všemi! Jesto my, nejhorši jsme jen služebnici! Má Bůh lepši kmeny ve svojéj vinici!"83

Doležal venuje pozornost' charakteristike mimozemských rozumných bytostí z hl'adiska ich telesnosti. Obyvatelia Mesiaca i planét majú byt' práve telesné bytosti (na rozdiel od netelesných anjelov):

„A když obyvatel zemský má své tělo, Jakžby to stvoření i tam ho nemělo? Nebo duch stvořený, nemůž po v̌̌s časy, Bez těla tělesné považovat krásy! Co pak ríci nevím, zvláště a osobně, Máli udy naším rovné a podobné?

Co se pak velkosti Měsíce dotýká, Téměr jest, jak naši té země, veliká;

On vzdálen jest, nad mil padesát tisíců, Máš-li křidla dobré, sám vylet'k Měsícu!

Sét.

Tenkrát tam nepůjdu! než snad se tam stavim! Když se s Gabrielem do nebe vypravim." 84 
I ked' si vo vyššie citovaných veršoch netrúfol odhadnút telesnú stavbu obyvatel'ov Mesiaca (v súvisiacich smeroch zašiel ovela d'alej napr. Christian Wolff ${ }^{85}$ a o vyše polstoročia po Doležalovi Gustáv Reuss), ${ }^{86}$ na neskoršom mieste -zrejme v súvislosti s predpokladom bezhriešnosti obyvatel'ov Mesiaca-uvažuje o inej ako „hrubohmotnej“ stavbe ich tiel:
„Můž tam i subtilnéjinší tělo žiti!
Nuž se ty domniváš́, aby každé tělo, tak hmotné, studené jak my udy mělo?
Těla jsou rozličná: my hle! máme zemská;
mohou býti jiná světlá a nebeská!
Jestli tedy Pán Bůh, i v těch světlech samých, chtěl osadit moudrých duchů slavných zdárných:
Co tebe do toho? To vše mohlo byti!
Můž tam i subtilné jinši tělo žiti!"87

Doležal sa nevyrovnáva s otázkou vzt'ahu predpokladanej bezhriešnosti mimozemštanov k Listu Rimanom 8,22 - 23: „Nebo víme, že všecko stvoření spolu lká a spolu ku porodu pracuje až posavad, a netoliko ono, ale i my, prvotiny Ducha majicí, i myt' také sami v sobě lkáme, zvoleni synů Božich očekávajíce, a tak vykoupení těla našeho." ${ }^{88}$ Podl'a tejto biblickej pasáže teda plačú spoločne všetky stvorenia vrátane nerozumných bytostí, rozumné bytosti potom plačú o to viac. ${ }^{89} \mathrm{Kým}$ pri argumentácii o koexistencii Boha a ničoty pred stvorením sveta dáva Doležal prednost' dogmatickým východiskám, v prípade zat'aženia obyvatel'ov iných nebeských telies hriechom akoby dával prednost' osvietensko-racionalistickým názorom. Stanovisko však zrejme závisí od exegetického prístupu. Doležal však nevysvetlil svoje chápanie tejto biblickej pasáže, ktoré preto ostáva nejasné. Ťažko si možno predstavit', že by sa bol vedome odklonil od Biblie. Doležal, rovnako ako iní prispievatelia Starých novín literního umění, často využíval vo svojich úvahách názory filozofov „ako pravdivé alebo nepravdivé východiská na ceste k logicky správnemu názoru“, ${ }^{90}$ ktorý však podl'a mienky Eriky Brtáňovej neprotirečí Písmu

85 V tretom zväzku Elementa matheseos universae (1735) Wolff navrhuje spôsob výpočtu výšky obyvatel'ov Jupitera založený na pomeroch telesnej vel'kosti, priemeru zornice a intenzity dostupného svetla (Crowe, c. d., s. 30).V slovenskom kontexte Anton Revický pri otázke, aké by mohli byt' vzrast, oči a povaha obyvatel'ov iných planét, odkazuje na štvrtý zväzok diela Spectacle de la Nature Noëla-Antoinea Pluchea (Karabová, c. d., s. 175)

86 Reuss uvažoval o anatomických danostiach obyvatel'ov Mesiaca v závislosti od prírodno-geografických podmienok a fyzikálnych vlastností prostredia (Reuss, c. d., s. 57 - 59).

87 Doleschalius, c. d., s. 230.

88 Biblj swata a neb wssecka swata pjsma, Starého y Nowého Zákona. W Presspůrku: Nákladem Cýs. Král. priw. Knihtlačitele Frant. August. Patzko, 1787, s. 196.

89 V tomto duchu S. Joannis Chrysostomi Archiep. Constantinop. In Epist. ad Rom. Homil. XIV. MIGNE, Jacques Paul (ed.): Patrologiae Graecae Tomus LX. Parisiis : Imprimerie Catholique, 1862, col. 531.

90 BRTÁŇOVÁ, Erika: Doležalov pokus o vel'kú epiku. In: TUREČEK, Dalibor - ZAJAC, Peter (eds.): Českýa slovenskýliterární klasicismus: synopticko-pulzační model kulturního jevu. Brno: Host, 2017, s. 258. 
svätému. ${ }^{91}$ Aj v Tragoedii „reflektuje myšlienkové prúdy svojej doby, ale zároveň jeho dielo stojí pevne na biblickom základe“.92

Miloslav Vojtech konštatuje, že v Doležalovej básni sa prejavuje „snaha zmierit' vieru a rozum“, ,teologické a racionalistické chápanie sveta“. ${ }^{93}$ Takéto úsilie je pritom charakteristické pre osvietenské myslenie a prejavuje sa aj v úvahách rozmanitých osvietenských autorov o pluralite svetov. Príkladom je tiež vyústenie Doležalovej argumentácie o obývanosti Mesiaca, podla mienky Evy Fordinálovej spočiatku „takmer zaváňajúcej sírovou herézou“.94

\author{
„Moudrého rozumu taková jest váha, \\ že ne jen $k$ Měsíci, než i $k$ hvězdám sahá! \\ Ba moc jeho, věr mi! takjestit'veliká, \\ že se on i trůnu Božího dotýká! \\ Byt'by mi Bůh nebyl, že JEST, sám povědèl, \\ Předce bych byl, že JEST, mým rozumem zvědèl!"95
}

Citované verše sa žiadnym spôsobom nevzd'alujú od stanoviska viery, ale predstavujú oslavu rozumu založenú na presvedčení, že rozum môže podat' dôkaz Božej existencie (ktorých poznáme z dejín filozofie množstvo). Svoj ontologický dôkaz predložil aj Leibniz, ${ }^{96} \mathrm{z}$ ktorého filozofie Doležal implicitne vychádza. ${ }^{97}$ Zmyslom danej pasáže, vyzdvihovanej ako prejav racionalistického optimizmu, ${ }^{98}$ je, že ak je rozum schopný dokázat' existenciu Boha, o to menší problém predstavuje podopriet ním tézu o existencii obyvatel'ov Mesiaca.

Christian Wolff sa zvlášt' zaujímal o leibnizovský racionalizmus ako o nástroj na zmierenie náboženstva a vedy, ${ }^{99}$ na spájanie viery so súdobými poznatkami prírodných vied. Jeho niekdajší žiak Lomonosov píše o Bazilovi Vel'kom a Jánovi Damaskom, usilujúcim sa podla neho zblížit prírodné poznanie a vieru, že keby disponovali možnostami, ktoré ponúka neskoršia astronómia, vykonané pozorovania by ich inšpirovali $k$ duchovne vzletnému a výrečnému hlásaniu

91 Tamže. Staršie názory Münz, Filozofia slovenského osvietenstva, c. d., s. 208.

92 Brtáňová, Doležalov pokus o vel'kú epiku, c. d., s. 208. Tiež Brtáňová, Podoby idylického v Doležalovej Tragoedii, c. d., s. 28; Brtáňová, Na pomedzí traktátového a románového žánru, c. d., s. 345.

93 VOJTECH, Miloslav: Od baroka k osvietenskému klasicizmu a preromantizmu. Literárnosmerové aspekty česky písanej poézie na Slovensku v prvej fáze národného obrodenia. In: Česká literatura na konci tisíciletí I. Praha : Ústav pro českou literaturu AV ČR, 2000, s. 136.

94 Fordinálová, c. d., s. 188.

95 Doleschalius, c. d., s. 228.

96 Na pozadí polemiky s Descartom. Podrobnejšie ANTOGNAZZA, Maria Rosa: Leibniz. In: OPPY, Graham (ed.): Ontological Arguments. Cambridge : Cambridge University Press, s. 75 - 98.

97 Na okraj podotknime, že logický dôkaz, že viditel'ný svet stvorila rozumná bytost', podáva vo svojej Rétorike i Wolffov niekdajši študent Michail Lomonosov. LOMONOSOV, Michail Vasilievič: Polnoje sobranije sočinenij. V 11 tomach. Tom 7. Moskva - Leningrad : Izdatel'stvo Akademii nauk SSSR, 1952, s. 324-326.

98 Münz, Filozofia slovenského osvietenstva, c. d., s. 51-52; Münz, Osvietenská filozofia, c. d., s. 209.

99 Crowe, c. d., s. 30. 
218 Božieho majestátu, múdrosti a moci. ${ }^{100}$ Oddeluje od seba oblast' prírodného sveta a sveta duchovného, založeného na Svätom písme: „Stvoritel'dal l'udskému rodu dve knihy. V jednej ukázal svoj majestát, v druhej svoju vôlu."101 Zmyslom stvorenia viditel'ného sveta $\mathrm{v}$ jeho kvalitách však podl'a neho je, „aby človek pri pohl'ade na ohromnost', krásu a usporiadanost' jeho stavieb uznal Božiu všemohúcnost' podl'a miery pochopenia, ktorým bol obdarovany'“ ${ }^{102}$

\title{
Nekonečná Božia moc, múdrost', vel'kost' a sláva
}

Doležalova Tragoedia patrí takisto k línii myslenia, ktorá považuje za zmysel stvorenia poznávanie nesmiernej Božej slávy. Idea nekonečnej moci Božej predstavovala v prípade nejedného myslitel'a ( $\mathrm{v}$ 13. storočí cirkevní hodnostári a učenci na univerzitách v Paríži a v Oxforde, v 14. storočí William z Ockhamu, Jean Buridan či Mikuláš z Oresme, v 15. storočí Mikuláš Kuzánsky) základ pre akceptáciu úvah o pluralite svetov. So silnejúcou rezonanciou témy mimozemského života vzrastala relevancia rozmanitých foriem argumentu Božej moci, múdrosti, velkosti a slávy ako prameňa legitimity myšlienky o existencii iných obývaných nebeských objektov.

Podobne ako Lomonosov, ktorý vidí zmysel stvorenia v tom, „aby človek pri pohl'ade na ohromnost', krásu a usporiadanost jeho stavieb uznal Božiu všemohúcnost' podl'a miery pochopenia“, aj Doležalove poetické reflexie predpokladajú, že „Pán Bůh proto stvořil dila, aby jeho sláva poznávaná byla“.103 Tieto myšlienky sa prelínajú s presvedčením, že poznávanie Božej slávy sa prejavuje uctievaním Boha:

\author{
„Jakož tedy Pán Bůh proto stvoril díla, \\ aby jeho sláva poznávaná byla: \\ tedy prám, jako nás stvoril na té zemi: \\ i v Měsíci onom medzi tvory všemi, \\ musí jen nějaký tvor rozumný býti, \\ jenžby tam, pro ten dar, mohl Boha ctiti.“104
}

Prostredníctvom postavy Adama autor reaguje na otázku, či sa táto sláva neprejavuje dostatočne tým, že nám mesiac ukazuje čas a svieti v noci. ${ }^{105}$ Ide o alúziu na verše knihy Genezis 1,14-15, podl'a ktorých „opět řekl Bůh: Bud'te světla na obloze nebeské, aby oddělovala den od noci, a byla na znameni a rozměrení časư, dnů a let. A aby svitila na obloze nebeské, a osvěcovala zemi. "106 Táto biblická pasáž

100 „Tak sa títo vel'kí svetlonosi usilovali spriatelit poznanie prírody s vierou a spájali jeho získanie $\mathrm{s}$ Bohom inšpirovanými myšlienkami v týchto knihách podla miery vtedajšieho astronomického poznania. Ó, keby vtedy muži, znalost'ou nebeských telies neporovnatel'ne prevyšujúci antických astronómov, vynašli súčasné astronomické prístroje a vykonali početné pozorovania, keby vtedy objavili tisícky nových hviezd s novými javmi, akým duchovným vzletom, spojeným s ich vynikajúcou výrečnostou, by títo svätí rečníci hlásali Boží majestát, múdrost' a moc!“ Lomonosov, Polnoje sobranije sočinenij 4, c. d., s. 375, pracovný preklad M. B.

101 Tamže, pracovný preklad M. B.

102 Tamže, pracovný preklad M. B.

103 Tamže, s. 228.

104 Doleschalius, c. d., s. 228.

105 Tamže, s. 229.

106 Biblj swata a neb wssecka swata pjsma..., c. d., s. [1]. 
pritom predstavovala jeden z argumentov používaných proti pluralite svetov. ${ }^{107}$

Oproti tomu Doležalov Adam argumentuje väčšou slávou stavby Mesiaca, ak Boha chvália aj jeho obyvatelia:

„Jak ty slávu Boži poznat můžeš z toho, čehož jest v Měsíci neomylně mnoho! Mnohém snad jinšiho Božího stvoření, než vidíš po všeckém té země staveni? Nuž to tam bez slávy Boži darmo stoji? Nikdo se tam Boha našeho neboji? Bylo byt' to pěkné vystavené město, v němž by k chlebu nikdy nebývalo těsto! Načež by to predce Bưh tam byl rozstavil, kdyby ho tam nikdo rozumný neslavil? Pravda sice, že i my Boha chválíme, kdyžv měsićném světle i v noci chodíme. Ale Bůh náš dobrý, nejdokonalejší, co jen může býti, činívá slavnější. A tak, když to Boži cti na odpor není, musí být v Měsíci rozumné stvoření!"108

V kontexte ruskej spisby dokazoval Michail Lomonosov v roku 1761 s oporou v citátoch cirkevných otcov (Bazil Vel'ký, Ján Damaský), že pravoslávna viera a veda si neprotirečia, ale že poznatky vedy vedú k uznaniu Božieho majestátu, múdrosti a moci. ${ }^{109}$ Svoje úvahy podoprel aj citátom slov Bazila Vel'kého o vztahu Božej moci a možnej plurality svetov: „Akoby hrnčiar, ktorý by vytvoril nespočetné množstvo nádob, napriek tomu nestratil svoje zručnosti a vnútornú silu, tak aj Stvoritel'všetkého, ktorý má tvorivú silu úmernú nie jednému svetu, ale je schopný nekonečného opakovania, stvoril viditelné svety v jedinom okamihu svojho želania."110 (Ako však napovedá odlišný preklad gréckeho originálu Bazilových slov, ${ }^{111}$ kontext homílie, autorovej osobnosti a doby, ide v nich skôr o odkaz na Origenovo učenie o striedaní vesmírov či kozmických vekov ${ }^{112}$ než o myšlienku plurality obývaných svetov v rámci aktuálneho univerza.) Lomonosov sa dotýkal idey nekonečnej Božej sily v bezprostrednej spätosti s predpokladom plurality svetov aj vo svojej poézii, osobitne v duchovných ódach Ranná úvaha o Božom majestáte (1743 alebo

107 Takto napr. Sentivániho Sústava sveta, Revického Základy prírodnej filozofie, druhá čast' alebo čiastková fyzika. Bližšie Zavarský, c. d., s. 22 -23, Karabová, c. d., s. 174.

108 Doleschalius, c. d., s. 229.

109 Pozri iSERMAN, Ilia Zacharovič: Poetič. stil'Lomonosova. Moskva-Leningrad: Nauka, 1966, s. 30-31.

110 Hexaemeron, Homilia I,3, pracovný preklad podla znenia citovaného v Lomonosovovom diele M. B. Lomonosov, Polnoje sobranije sočinenij 4, c. d., s. 374.

111 „Lebo ako hrnčiar vyformuje nespočetné množstvo nádob tým istým umením a nevyčerpá tým ani svoje umenie ani silu, takisto to platí o Tvorcovi tohto všetkého, ktorého stvoritel'ská moc sa nedá merat' jedným kozmom, ale prechádza do nekonečného násobku; On čírym podnetom svojej vôle priviedol do bytia obrovské priestory viditel'ného sveta." Bazil Vel'ký, c. d., s. 183.

112 O ňom podrobne SERIOGIN, Alexandr Vasilievič: Gipoteza množestvennosti mirovv traktate Origena „O načalach“. Moskva : Institut filosofii Rossijskoj Akademii Nauk, 2005. 
$2201749-1751)^{113}$ a najmä Večerná úvaha o Božom majestáte pri príležitosti vel'kej polárnej žiary (1743). ${ }^{114}$ Podobné pasáže možno nájst' i v duchovných ódach iných ruských autorov, vrátane básne Zo žalmu 106 Alexandra Sumarokova $(1755),{ }^{115}$ na základe ktorej napísal v roku 1755 významný básnik Vasilij Trediakovskij na Sumarokove udanie na Najsvätejšiu synodu Ruskej cirkvi. ${ }^{116} \mathrm{~V}$ podobnom duchu ako Lomonosovove a Sumarokovove verše sú ladené tiež úvodné časti ódy Michaila Cheraskova Svet (1778) ${ }^{\mathbf{1 1 7}}$ a óda Gavrila Deržavina Boh (1784). ${ }^{118}$ V týchto básňach sa prepletajú idey nekonečnosti kozmu a plurality svetov s oslavou Božej sily a majestátu, ${ }^{119}$ čo predstavuje istú spojnicu aj so slovenským literárnym kontextom.

\section{Ohlasy Eseje o človeku}

Ďalším spisovatel'om, ktorý ovplyvnil reflexiu témy plurality svetov osvietensky orientovanými autormi, bol anglický básnik Alexander Pope. Bohuslav Tablic v roku 1817 preložil, po zásadnom prepracovaní však až v roku 1831 uverejnil preklad jeho rozsiahlej filozofickej básne Esej o člověku (1734), ktorú vysoko hodnotil Voltaire a inšpiroval sa ňou vo svojich Veršovaných rečiach o človeku (1734-1737). Báseň v prvej zo štyroch epištol hovorí aj o obyvatel'och nespočetných svetov („Ve světech ačkoli Bưh bezpočtných znám stvořením jest"), resp. iných planetárnych systémov (,všecky planéty zná, viokol sluncí se točící, / každičké hvězdy všeliké též bydlitele $z$ ná"): $:^{120}$
„Rciž najprvé, což o Bohu v výsosti, co můžem
odjinud o člověku zde zavírat, nežz toho, což vím?
Což tu dole z člověka zrím víc, než byt jeho zemský
od něho, neb-li na něj závěrky všecky se táhnou?
Ve světech ačkoli Bůh bezpočtných znám stvořenim jest,
nám v světě jen tomto šlepěji jeho šetřiti dlužno.
Ten, jenž skrz spoustnou nesmirnost může proniknout,
zřít světy na světech a spojovat vše $v$ Všechnotu jednu,
soustavy jedné vplyv znamená ve jinou obapolným
všecky planéty zná, vưkol slunci se točicí,
každičké hvězdy všeliké též bydlitele zná, necht' řeknt', nebe proč tak, jakž jsme, sformovalot' nás.

113 LOMONOSOV, Michail Vasilievič: Polnoje sobranije sočinenij. V11 tomach. Tom 8. Moskva-Leningrad : Izdatel'stvo Akademii nauk SSSR, 1959, s. 117 - 119.

114 Tamže, s. $120-123$.

115 [SUMAROKOV, Alexandr Petrovič]: Ody duchovnyja. Izo Psal'ma CVI. In: Ježemesiačnyja sočinenija..., Sent'abr, 1755 goda. V Sanktpeterburge : pri Imperatorskoj Akademii Nauk, 1755, s. 253 - 255.

116 Úplný text TREDIAKOVSKIJ, Vasilej: Izvet na A. P. Sumarokova. In: Moskvitáanin. Učebno-literaturnyj žurnal, 1856, tom IV, № 13 - 16. Moskva : V tipografii L. Stepanovoj, 1857, s. 271 - 276. Ku kontextu udalosti pozri PEKARSKIJ, Petr: Istorija Akademii Naukv Peterburge... Tom vtoroj. Sanktpeterburg : Izdanie Russkago jazyka i slovesnosti Imperatorskoj Akademii Nauk, 1873, s. 187.

117 CHERASKOV, Michail: III. Oda mir. In: Utrennij svet... Čast'II. Mesiac Janvar. V Sanktpeterburge : v Tipografii Imperatorskago Suchoputnago Šlachetnago Kadetskago Korpusa, 1778, s. 74 - 76.

118 [DERŽAVIN, Gavriil Romanovič]: Bog. In:Sobesednik lubitelej rossijskago slova..., čast' XIII. V Sanktpeterburge : iždivenijem Imperatorskoj Akademii Nauk, 1784, s. 125 - 129.

119 Vybrané citáty z diel sú dostupné v štúdii Braxatoris, c. d., s. 87 - 88.

120 Riadky 17 - 34. POPE, Alexander: An Essay on Man. With notes by William Warburton. Dublin : Printed by George Perrin, 1791, s. 9-10. 
též stroje vazby, tuhé spojeni všech v jednotu částek,

útou záviselost, $k$ tomu slušné postupování,

či snad zderžovati zvláštni celotu lze je částce?

Přehrozný-li řetěz, jenž všecko v jednotu viže,

A stažené třimá, sám ty zdržuješ, nebo sám Bůh?"“121

Popeova báseň bola v priebehu kultúrnych dejín podrobená množstvu interpretačných deformácií, preto treba i citovanú pasáž vnímat' obozretne. Jej verše hovoria aj o mimozemskom živote, nejde v nich však o rozvíjanie naturalistických filozofických stanovísk. Poukazuje na to poznámka Popeovho editora a priatela Williama Warburtona k veršu ,útlou záviselost, ktomuslušnépostupováni“:

„Soustava veškerého světa (všechnoty) jestit'spojení př́rodních a mravných schopností, jako lidská soustava, tèlesných a duchovnich. Skrze tuhá spojení tedy naráží básniř na prírodné, a skrze útlé záviselosti na mravné schopnosti. Poněvádž zkouška o člověku neni soustava o prírodnosti (naturalismu), ale přirozeného náboženství: odtud pochodí, že kde napred klade básnír, že nepořádky maji směřovati kněkterému většímu dobru ve mravném svètě..." 122

Pri prvej zo zmienok o pluralite svetovide to, že i ked'je Boh známy v nespočetných svetoch, ludskou úlohou je kráčat' v pozemskom svete v jeho stopách na ceste k mravnej dokonalosti. Druhá zmienka sa týka Božej vel'kosti v kontraste s ohraničenostou ludského poznania a schopností, ktorá okrem iného podporuje predchádzajúcu tézu o úlohe človeka vo svete. Posolstvo textu i citovanej pasáže je nábožensko-etické a v konečnom dôsledku osvietensko-výchovné, nie však naturalistické. Tablic sa v predslove svojho prekladu o Popeovom diele vyjadril:

„Cíl Popův, který sobě pri této knize představil, jest: hlubokou vážnost k Bohu a vysoké o něm myšlení v mysli člověka vzbuditi, jej k poslušnému opatrování ponouknuti, v něm lásku k moudrému a dobrotivému Bohu roznititi a naposledy člověku cestu ctnosti jakožto jedinou k pravé blaženosti vedoucí ukázat, a jej spolu i k plnění těch povinností, kteréjinim podlužen jest, podnititi.“123

Pri formovaní Tablicovej osvietenskej myšlienkovej orientácie ${ }^{\mathbf{1 2 4}}$ zohralo zásadnú rolu nemecké univerzitné prostredie v Jene, ${ }^{125}$ hoci nemožno prehliadat' ani vplyv slovenského či širšie uhorského kontextu (vrátane prostredia, ktoré

121 TABLIC, Bohuslav: Anglickémúzy v česko-slovenském oděvu... V Budíně:V Král. universické tiskárně, 1831, s. $2-3$.

122 Tamže, s. 3; anglický originál Pope, c. d., s. 10.

123 Tablic, Anglické múzy v česko-slovenském oděvu, c. d., s. IX - X.

124 Na ktorej rozplývavost' poukazuje Valér Mikula v práci MIKULA, Valér: Bohuslav Tablic a osvietenstvo. In: Slovenská literatúra, roč. 44, 1997, č. 2, s. $153-163$.

125 O tom detailne na rôznych miestach svojej monografie BRTÁŇ, Rudo: Bohuslav Tablic (1769-1832): život a dielo. Bratislava : Veda, 1974. RIŠKOVÁ, Lenka: Básnické umenie podl'a Bohuslava Tablica. Bratislava : Ústav slovenskej literatúry SAV, 2014, s. 17. 
222 naňho vplývalo počas jeho štúdia na bratislavskom evanjelickom lýceu). ${ }^{126} \mathrm{Na}$ jej utváraní sa osobitne podiel'alo neskoršie Tablicovo čítanie zahraničnej literatúry a jeho prekladatel'ská aktivita, determinovaná jeho záujmom o francúzštinu a angličtinu, ${ }^{127}$ ktoré študoval na univerzite v Jene. Tablicovi patrí prvenstvo medzi slovenskými básnikmi, ktorí venovali sústredenú pozornost' anglickej poézii. ${ }^{128}$ Spolu s Františkom Palackým a Josefom Jungmannom zastáva popredné miesto medzi staršími prekladatel'mi z angličtiny do češtiny. ${ }^{129} \mathrm{O}$ význame Popea v Tablicovej lektúre svedčí aj to, že jeho knihy umiestnil do svojej ideálnej knižnice v básni Slobodnévolení:

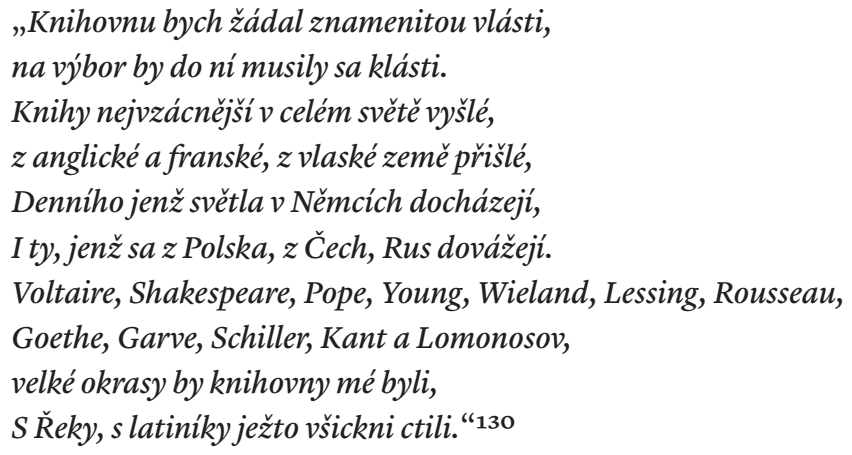

Za zmienku stojí tiež fakt, že v zozname sa nachádzajú aj diela d'alších autorov rozvijajúcich myšlienku plurality obývaných svetov, najmä Michaila Lomonosova, ktorého preklad sa Tablic neúspešne pokúšal vydat', ${ }^{131}$ Edwarda Younga, ${ }^{132}$ ktorého ukážky prekladal, či Voltaira ${ }^{133}$ a Immanuela Kanta, ${ }^{134}$ ktorých myšlienky naňho pôsobili počas štúdií v Jene. Je nanajvýš pravdepodobné, že Tablic bližšie poznal aj pluralistické názory týchto autorov.

Lenka Rišková uvádza, že Alexander Pope a George Lyttelton, ${ }^{135}$ ktorých Tablic prekladal z angličtiny (popri Williamovi Shakespearovi a Edwardovi Youngovi), „už mohli mat'v uhorskom kontexte istú - i ked' nie príliš výraznú - recepčnú tradíciu“. ${ }^{136}$ Do pol'štiny ${ }^{137}$ i do ruštiny ${ }^{138}$ sa pritom Popeovo dielo prekladalo najskôr z francúzštiny, jazykové kompetencie umožňovali Tablicovi vychádzat' z anglického originálu, i ked'ovládal aj francúzštinu a poznal tiež latinský preklad

126 RIŠKOVÁ, Lenka: K formovaniu Tablicových literárnych názorov. In: Slovenská literatúra, roč. 54, 2007 , č. 5 , s. $357-361$.

127 Brtáň, Pri prameňoch slovenskej obrodeneckej literatúry, c. d., s. 133.

128 Brtáň, Bohuslav Tablic, c. d., s. 259.

129 Tamže.

130 TABLIC, Bohuslaw: Poezye. Djl prwnj. Wacow : Antonjn Gotljb, 1806, s. 13.

131 Brtáň, Bohuslav Tablic, c. d., s. 259.

132 Crowe, c. d., s. 26, 43, 84, 86.

133 Pripomenút treba najmä jeho Micromégas.

134 Crowe, c. d., s. 47 a n.; Szendy, c. d.

135 Lytteltonove Básně tvorili druhú čast' edície Anglické múzy v česko-slovenském oděvu, v ktorých vyšla Popeova Zkouška o člověku.

136 Rišková, Básnické umenie podla Bohuslava Tablica, c. d., s. 30.

137 Tamže, s. 259-260.

138 Pozri nižšie. 
básne, ktorý ovplyvnil jeho časomerné prebásnenie pôvodného, dnes nezacho- 223 vaného prízvučného prekladu. ${ }^{139}$ Rudo Brtáň vo vztahu k Tablicovmu prekladu konštatoval oneskorenost', súvisiacu s prioritou etického zámeru diela, ${ }^{\mathbf{1 4 0}}$ ako aj s povahou východiskového textu a metra zvoleného pre jeho preklad. ${ }^{141}$ Svoje konštatácie podložil dobovými literárnymi súvztažnostami (situácia „pred križovatkou klasicizmu a romantizmu“) a nadviazal na ne myšlienkou o súvisiacom malom recepčnom dosahu prekladu. ${ }^{142}$ Brtáňove závery, na ktoré afirmatívne nadväzuje aj Miloslav Vojtech, ${ }^{143}$ sa pritom týkajú najmä vydaného prekladového diela ako súčasti literárnej komunikácie. Spomína však, že Tablic pôvodne zložil prízvučný preklad básne, ${ }^{144}$ ktorý bol dokončený už v roku 1817, po prepracovaní ho predložil cenzúre až v roku 1827 a pre problémy s výberom tlačiarne, cenou, zásahmi korektorov a kvalitou tlače ho napokon uverejnil v roku $1831 .^{145}$

Je zrejmé, že prítomnost' pasáže o pluralite svetov v ináč obsiahlom texte prekladanej Eseje o človeku nemožno z literárnohistorického hl'adiska preceňovat', čo platí o to skôr, že recepčný dosah prekladu mohol byt' v dôsledku vyššie spomínaných okolností obmedzený. Iná situácia bola v ruskom literárnom kontexte, ktorého špecifiká súviseli aj s nevyrovnanostou cirkevných autorít s možnostou literárnej tematizácie plurality svetov. Na dôvažok, do ruštiny bola Esej o človeku preložená o vyše polstoročie skôr, i ked' z francúzskeho prekladu. Postaral sa o to v roku 1754 Lomonosovov žiak Nikolaj Popovskij, ktorý ju preložil pod vedením a zrejme aj na podnet svojho učitel'a. ${ }^{146}$ Po uverejnení prekladu Fontenellovho diela pritom išlo o druhý významný počin, ktorým sa do ruskej literatúry uviedla téma plurality svetov. Táto literárna udalost' prebehla na pozadí konfliktných vztahov Lomonosova a jeho okolia s Najsvätejšou synodou Ruskej cirkvi viažucich sa na ideu plurality svetov. V roku 1756 Najsvätejšia synoda zabránila vydaniu prekladu N. Popovského pre „naturalistické“ a kopernikovské východiská, myšlienky o pluralite svetov a pre údajný nesúlad so Svätým písmom. ${ }^{147} \mathrm{~V}$ roku 1757 vyšla so zásahmi metropolitu moskovského Ambróza, ktorý nahradil nekonformné časti vlastnými veršami. ${ }^{148} \mathrm{~V}$ tom istom roku Lomonosov vystúpil voči predstavitel'om Ruskej cirkvi ostrou satirickou básňou Hymnus na bradu, ${ }^{149} \mathrm{v}$ ktorej sa okrem iného uvádzalo, že planéty sú podobné svety ako ten náš. Hymnus vyvolal pobúrenú reakciu Najsvätejšej synody, ktorá sa s odkazom na vtedajšiu legislatívu dožadovala, aby cárovná nechala báseň zničit', verejne spálit', v budúcnosti

\footnotetext{
139 Brtáň, Bohuslav Tablic, c. d., s. 260.

140 Tamže, s. 263.

141 Tamže, s. 267.

142 Tamže.

143 VOJTECH, Miloslav: Problematika medziliterárnosti a dejín umeleckého prekladu v monografii Ruda Brtáňa venovanej Bohuslavovi Tablicovi. In: Slovenská literatúra, roč. 66, 2019, č. 5, s. 353 - 354.

144 O ňom sa zmieňuje samotný Tablic, Anglické múzy v česko-slovenském oděvu, c. d., s. V - VI.

145 Brtán̆, Bohuslav Tablic, c. d., s. 261.

146 Kulikovskij, c. d., s. 52.

147 Polnoje sobranije postanovlenij i rasporiaženij po vedomstvu pravoslavnago ispovedanija Rossijskoj Imperii. Tom IV. Sanktpeterburg : Sinodalnaja tipografija, 1912, s. 238-239.

148 POPE, Alexandr: Opyt o čeloveke Gospodina Pope. Perevedeno... Nikolajem Popovskim 1754 goda. Moskva : Pečatano pri Imperatorskom Moskovskom Universitete, 1757. Zásahy cenzora sú vyznačené vel'kým písmom.

149 Gimn Borode. In: Lomonosov, Polnoje sobranije sočinenij 8, c. d., s. 618 - 626.
} 
224 aby zakázala podobnú tvorbu a aby jej autora nechala predviest' pred samotnú synodu. ${ }^{150}$ Vystúpenie cirkvi nemalo pre Lomonosova žiadne dôsledky (krátko na to ho dokonca vymenovali do akademickej funkcie), vyvolalo však živú literárnu výmenu listov, satirických diel a epigramov, ${ }^{151}$ vrátane básne Preoblečená brada alebo hymnus na opitú hlavu, a satirických diel pripisovaných samotnému Lomonosovovi. ${ }^{152}$

\section{Záver}

V traktátovej literatúre slovenskej proveniencie bola téma plurality svetov prítomná od 17. storočia. Začiatok jej rozvíjania v poézii písanej vo vernakulárnom jazyku sa spája s obdobím, ked'na Slovensku vrcholil, resp. vytrvalo prežíval vplyv osvietenských ideí. Tému reprezentujú viaceré pasáže z Doležalovej Tragoedie, ktoré špecificky nadväzujú na východiská leibnizovsko-wolffovskej filozofie. I ked' sú pluralistické predpoklady významné v systéme teodícey, ktorým sa Doležal inšpiroval, v Tragoedii plnia menej dôležitú funkciu, ked'v reflexiách o dopustení zla absentujú kozmické rozmery. ${ }^{153}$ Prekladovú poéziu obohatil o túto tému Tablicov preklad Popeovej Eseje o človeku, ktorý rovnako treba vidiet'v širších ideových a estetických kontextoch, kde daná otázka nie je dominantná. Tieto aspekty skúmaných diel sú relevantné predovšetkým z tematologického hladiska. Napriek časovým, kvantitatívnym a iným špecifikám možno konštatovat', že slovenská poézia sa v tomto smere vyvíjala v zásade podobne ako iné európske literatúry. V ruskom kontexte téma silno rezonovala $v$ epoche osvietenstva: $v$ rámci prekladovej a originálnej traktátovej spisby sa ňou v 18. storočí zaoberali Antioch Kantemir a Michail Lomonosov, do básnickej tvorby ju uviedol Michail Lomonosov, rozvíjali ju Nikolaj Popovskij, Gavril Deržavin, Alexandr Sumarokov a Michail Cheraskov. Slovenská aj ruská literatúra v tomto smere čerpajú z rovnakých prameňov vrátane Gottfrieda Wilhelma Leibniza, Christiana Wolffa a Alexandra Popea. Za zmienku stoja podobné črty Lomonosovovej a Doležalovej reflexie danej témy, ktoré súvisia s Lomonosovovým štúdiom u Christiana Wolffa na univerzite v Marburgu (1736-1739) a s Doležalovým štúdiom v nemeckom Altdorfe $(1760-1762)$. Spojnicu medzi tvorbou slovenského a ruského autora nepredstavuje len ich vnímanie otázky, či sú obyvatelia iných vesmírnych telies zatažení prvotným hriechom, ale aj spôsob reflexie plurality svetov v kontexte poznávania nekonečnej Božej slávy.

Štúdia je výstupom grantového projektu VEGA 2/0117/17 Príležitostná básnická tvorba Juraja Palkoviča, Bohuslava Tablica a Pavla Jozefa Šafárika. Zodpovedná riešitel'ka: Mgr. Lenka Rišková, PhD. Doba riešenia: 2017 - 2020.

150 Polnoje sobranije postanovlenij i rasporiaženij... IV, c. d., s. 282 - 283.

151 Pekarskij, c. d., s. 205, 604; MENŠUTKIN, Boris Nikolajevič (ed.): Michajlo Vasilievič Lomonosov. Žizneopisanie. 4-je izdanie. Sanktpeterburg : Tipografija Imperatorskoj Akademii Nauk, 1912, s. 98; ZAPADOV, Alexandr Vasilievič: Poety XVIII veka (M. V. Lomonosov, G. R. Deržavin). Moskva : Izdatel'stvo Moskovskogo universiteta, 1979, s. 117 a n.

152 Pozri Lomonosov, Polnoje sobranije sočinenij 8, c. d., s. 627-630.

153 Najmä v $\$ 153$ Duchovné zatmnění světu neškodí (Doleschalius, c. d., s. 185 - 187) by sa dala očakávat' prítomnost pluralistických prvkov, argumentácia sa však týka výhradne Zeme. 
BAZIL VEL'KÝ, Sv.: Listy II. (r. 375 - 378), Hexaémeron. Preložil Daniel Škoviera. Prešov : Náboženské vydavatel'stvo Petra, 2002, s. 183.

Biblj swata a neb wssecka swata pjsma, Starého y Nowého Zákona. W Presspůrku : Nákladem Cýs. Král. priw. Knihtlačitele Frant. August. Patzko, 1787.

[DERŽAVIN, Gavriil Romanovič]: Bog. In: Sobesednik lubitelejrossijskago slova..., čast' XIII. V Sanktpeterburge : iždivenijem Imperatorskoj Akademii Nauk, 1784, s. 125 - 129.

DOLESCHALIUS, Augustinus: Pamětná CELÉMU SWĚTU TRAGOEDIA, anebožto Werssowné Wypsánj žalostného Prwnjch Rodičů Pádu... W Vherské Skalicy: Wytisstěná v Jozeffa Antonjna Sskarnycla, 1791. FEOFAN ZATVORNIK, sviatitel': Pravoslavie inauka. Rukovodstvennaja kniga izrečenij i poučenij. Moskva : Danilovskij Blagovestnik, 2005.

FONTENELLE, Bernar Le Bovie de: Razgovory o množestve mirov...: $\mathrm{s}$ francuzskago perevel i potrebnymi primečanijami izjasnil Kňaz Antioch Kantemir v Moskve 1730 godu. Sanktpeterburg : Pri Imperatorskoj Akademii Nauk, 1740.

FONTENELLE, Bernard Le Bovier de: Entretiens sur la pluralité des mondes, suivis des Dialogues des morts. Nouvelle édition. Parisis : e l'imprimerie d' Aug. Delalain, 1822.

Hvizdna kapura alebo Dobrodružstvá Krutohlava [DIVADLO - PegasCon 2017].[cit. 2020-05-02]. Dostupné na: https://youtu.be/ tkc85FCPCKk

CHERASKOV, Michail: III. Oda mir. In: Utrennij svet. Ježemesiačnoje izdanije. Čast' II. Mesiac Janvar. V Sanktpeterburge : v Tipografii Imperatorskago Suchoputnago Šlachetnago Kadetskago Korpusa, 1778, s. $74-76$.

LEIBNIZ, Gottfried Wilhelm: Theodicy. Essays on the Goodness of God, the Freedom of Man and Origin of Evil. Translator E. M. Guggard, editor Austin M. Farrer. New York : Cosimo, 2009.

LOMONOSOV, Michail Vasilievič: Polnoje sobranije sočinenij. V 11 tomach. Tom 4; Tom 7; Tom 8. Moskva - Leningrad : Izdatel'stvo Akademii nauk SSSR, 1955; 1952; 1959.

MIGNE, Jacques Paul (ed.): Patrologiae Graecae Tomus LX. Parisiis : Imprimerie Catholique, 1862.

PAVLAC, Peter: Krutohlavova cesta na Mesiac. [Rozhlasová hra napísaná z pojednania Hviezdoveda Gustáva Reussa z roku 1857.] Sobota 27. 9. 2014. Rozhlasové hry - archív extra. [cit. 2020-05-02]. Dostupné na: https://www.rtvs.sk/radio/archiv/1365/54446

Polnoje sobranije postanovlenij i rasporiaženij po vedomstvu pravoslavnago ispovedanija Rossijskoj Imperii... Tom IV. Sanktpeterburg: Sinodalnaja tipografija, 1912.

POPE, Alexander: An Essay on Man. With notes by William Warburton. Dublin : Printed by George Perrin, 1791.

POPE, Alexandr: Opyt o čeloveke Gospodina Pope. Perevedeno... Nikolajem Popovskim 1754 goda. Moskva: Pečatano pri Imperatorskom Moskovskom Universitete, 1757.

PUŠKIN, Alexander/Alexandr Sergejevič: Jevgenij Onegin : Roman v stichach/Eugen Onegin : Román vo veršoch. Prel. Ján Štrasser. Bratislava : Petrus, 2002.

REUSS, Gustáv: Hviezdoveda. Bratislava : Tatran, 1984.

SCHAFFARIK, Paul Joseph: Geschichte der slawischen Sprache und Literatur nach allen Mundarten. Ofen : mit Kön. Ung. Universitäts Schriften, 1826.

[SUMAROKOV, Alexandr Petrovič]: Ody duchovnyja. Izo Psal'ma CVI. In: Ježemesiačnyja sočinenija kpolze i uveseleniju služaščija. Sentabr, 1755 goda. V Sanktpeterburge : pri Imperatorskoj Akademii Nauk, 1755 , s. $253-255$. 
226 TABLIC, Bohuslav: Anglickémúzy w česko-slowenském oděwu. Alexandra Pópa... Zkauška o člowěku; s poznamenánjmi Warburtonowými z anglického gazyka přeložil B. T. : Girjho Lorda Littletona Básně. W Budíně : W Král. Universické tiskárně, 1831.

TABLIC, Bohuslaw: Poezye. Djl prwnj. Wacow : Antonjn Gotljb, 1806. TREDIAKOVSKIJ, Vasilej: Izvet na A. P. Sumarokova. In: Moskvit'anin. Učebno-literaturnyj žurnal, tom IV, 1856, № 13 -16. Moskva : V tipografii L. Stepanova, 1857, s. $271-276$.

\section{Literatúra}

ANTOGNAZZA, Maria Rosa: Leibniz. In: OPPY, Graham (ed.): Ontological Arguments. Cambridge : Cambridge University Press, s. 75 - 98.

BELLIS, Delphine: Imaginary Spaces and Cosmological Issues in Gassendi's Philosophy. In: BAKKER, Frederik - BELLIS, Delphine PALMERINO, Carla Rita (eds.): Space, Imagination, and the Cosmos, from Antiquity to the Early Modern Period. Dordrecht: Springer, 2018, s. $233-260$.

BOBINE, Georgij: Filosofskije vozzrenija Antiocha Kantemira. Kišiňov : Štiinca, 1981.

BRAXATORIS, Martin: Ideja množestva mirov. Primery iz russkoj i slovackoj poezii XVIII veka. In: Devin : Almanach Obščestva L'udovita Štura v Moskve. Moskva : MIK, roč. 5, 2019, č. 2, s. 81 - 97.

BRTÁŇ, Rudo: Bohuslav Tablic (1769-1832): život a dielo. Bratislava : Veda, 1974.

BRTÁŇ, Rudo: Pri prameňoch slovenskej obrodeneckej literatúry. Bratislava : Vydavatel'stvo Slovenskej akadémie vied, 1970.

BRTÁŇOVÁ, Erika: Doležalov pokus o vel'kú epiku. In: TUREČEK, Dalibor - ZAJAC, Peter (eds.): Český a slovenský literární klasicismus : synopticko-pulzační model kulturního jevu. Brno: Host, 2017, s. $245-271$.

BRTÁŇOVÁ, Erika: Na pomedzí traktátového a románového žánru. In: Slovenská literatúra, roč. 54, 2007, č. 5, s. 338-346.

BRTÁŇOVÁ, Erika: Podoby idylického v Doležalovej Tragoedii. In: Slovenská literatúra, roč. 65, 2018, č. 1, s. 27 - 36.

BRUNO, Giordano Nolano: De l'infinito, universo e mondi : Stampato in Venezia, Anno MDLXXXIV. In: Dialoghi filosofici italiani, a cura di Michele Ciliberto. Milano : Mondadori, 2000.

CLAIRE, Bouyre: Vivre et Aller sur la Lune en 1640? Les sciences du vivant dans le discours sur la pluralité des Mondes, à partir de l'œuvre de John Wilkins: The Discovery Of A New World (1640). In: Bulletin d'Histoire et d'épistémologie des Sciences de la vie, roč. 21, 2014, č. 1, s. $7-37$.

CROWE, Michael J.: The Extraterrestrial Life Debate 1750-1900: The Idea of a Plurality of Worlds from Kant to Lowell. Cambridge : Cambridge University Press, 1988.

DĚDINOVÁ, Tereza: Úvodní slovo aneb Jak (ne)definovat fantastiku. In: DĚDINOVÁ, T. (ed.): Na rozhrani světů : fantastická literatura v mezioborovém zkoumání. Brno : Filozofická fakulta, Masarykova univerzita, 2016, s. 9-24.

DICK, Steven J.: Plurality of Words: The Extraterrestrial Life Debate from Democritus to Kant. Cambridge : Cambridge University Press, 1984 (prvé vydanie 1982).

ECO, Umberto: Inventing the Enemy and Other Occasional Writings. Translated from the Italian by Richard Dixon. Boston - New York : Houghton Mifflin Harcourt, 2012.

ERNST, Germana: Tommaso Campanella: The Book and the Body of Nature. Translated by David L. Marshall. Dordrecht - HeidelbergLondon - New York : Springer, 2010.

FERKO, Miloš: Prvý slovenský sci-fi román. In: Historická revue, roč. 7, 1996, č. 5, s. 33. 
FORDINÁLOVÁ, Eva: Stretnutie so starším pánom. Martin : Osveta, 1993.

GLUCHMAN, Vasil: The Origin of Evil and Benefits of Sin. In: HARRIS, Harriet A. (ed.): God, Goodness and Philosophy. London-New York : Routledge Taylor \& Francis Group, 2016, s. 209-216.

GRANT, Edward:Planets, Stars and Orbs. The Medieval Cosmos, $1200-$ 1687. Cambridge : Cambridge University Press, 1996 (prvé vydanie 1994).

HARRISON: Edward Robert: Darkness at Night: A Riddle of the Universe. Cambridge - Massachusetts - London : Harvard University Press, 1987.

HARRISON, Edward: Masks of the Universe. Changing Ideas on the $\mathrm{Na}$ ture of the Cosmos. Cambridge: Cambridge University Press, 2003.

KARABOVÁ, Katarína: Problematika mimozemských civilizácií z pohl'adu novolatinských spisov z oblasti fyziky. In: ŠKOVIERA, Daniel-SIPEKIOVÁ, Nicol (eds.): Sambucus IX. Trnava - Kraków : Filozofická fakulta Trnavskej univerzity v Trnave - Towarzystwo Słowaków w Polsce, 2013, s. 168 - 178.

KONDAKOV, Ivan Petrovič (ed.): Svodnyj katalog knig graždanskoj pečati XVIII veka. 1725 - 1800. Tom 3. R-Ja. Moskva : Kniga, 1966.

KULIKOVSKIJ, Petr Grigorievič: M. V. Lomonosov-astronom i astrofizik. Izd- 2-je. Moskva : Gos. izd-vo fiz.-mat. lit., 1961.

MENŠUTKIN, Boris Nikolajevič (ed.): Michajlo Vasilievič Lomonosov. Žizneopisanie. 4-je izdanie. Sanktpeterburg: Tipografija Imperatorskoj Akademii Nauk, 1912.

MIKULA, Valér: Bohuslav Tablic a osvietenstvo. In: Slovenská literatúra, roč. 44,1997, č. 2 , s. $153-163$.

MOMDŽIAN, Chačik Nišanovič: Francuzskoje prosveščenije XVIII veka: Očerki. Moskva : Mysl', 1983.

MÜNZ, Teodor: Filozofia slovenského osvietenstva. Bratislava: Slovenská akadémia vied, 1961.

MÜNZ, Teodor: Osvietenská filozofia. In: Dejiny filozofického myslenia na Slovensku I. Bratislava : VEDA, 1987, s. 203 - [285].

PEKARSKIJ, Petr: Istorija Akademii Nauk v Peterburge... Tom vtoroj. Sanktpeterburg: Izdanie Russkogo jazyka i slovesnosti Imperatorskoj Akademii Nauk, 1873.

REGIS, Edward Jr. (ed.): Extraterrestrials: Science and Alien Intelligence. Cambridge - London - New York - New Rochelle - Melbourne Sydney : Cambridge University Press, 1987.

RIŠKOVÁ, Lenka: Básnické umenie podl'a Bohuslava Tablica. Bratislava : Ústav slovenskej literatúry SAV, 2014.

RIŠKOVÁ, Lenka: K formovaniu Tablicových literárnych názorov. In: Slovenská literatúra, roč. 54, 2007, č. 5, s. $357-371$.

SERIOGIN, Alexandr Vasilievič: Gipoteza množestvennosti mirovv traktate Origena „O načalach“. Moskva : Institut filosofii Rossijskoj Akademii Nauk, 2005.

SERMAN, Ilia Zacharovič: Poetičeskij stil'Lomonosova. Moskva - Leningrad : Nauka, 1966.

SRPOŇ, Vlado: Dr. Gustáv Maurícius Reuss: Prvý literárny fantasta Horného Uhorska? In: Interkom, 1993, č. 11-12. [cit.2020-05-02]. Dostupné na: http://interkom.vecnost.cz/1993/19931116.htm

SZENDY, Peter: Kant in the Land of Extraterrestrials: Cosmopolitical Philosofictions. Translated by Will Bishop. New York : Fordham University Press, 2013 (francúzsky originál 2011).

ŠIŠKIN, I. [akinf Ivanovič]: Michail Abramov - odin iz protivnikov Petrovskoj reformy. In: Nevskij sbornik (učebno-literaturnyj). S.-Peterburg : Izdanie Vl. Kuročkina, 1867, s. 375 - 429.

THJISSEN, Hans: Condemnation of 1277. In: ZALTA, Edward N. (ed.): Stanford Encyclopedia of Philosophy. Stanford : Metaphysics Research Lab. CSLI, Stanford University, 2018. [2020-05-02]. Do- 

condemnation/

TRONSKIJ, Iosif Moisejevič: Dějiny antickéliteratury. II. díl. Římská lite-

'o ratura. Praha: Nakladatelství Československé akademie věd, 1956.

Оิ VLČEK, Jaroslav: Osvícenské Slovensko evangelické. In: Literatura česká

이 devatenáctého století. Díl první:od Josefa Dobrovského kJungmannově

స゙ škole básnické. Praha : Jan Laichter, 1902, s. 633-647.

Ð. VOJTECH, Miloslav: Od baroka k osvietenskému klasicizmu a pre-

'0 romantizmu. Literárnosmerové aspekty česky písanej poézie na Slovensku v prvej fáze národného obrodenia. In: Českáliteratura na konci tisiciletíl. Př́spěvkyz 2. kongresu světovéliterárněvědnébohemistiky. Praha : Ústav pro českou literaturu AV ČR, 2000, s. 135-144.

VOJTECH, Miloslav: Problematika medziliterárnosti a dejín umeleckého prekladu v monografii Ruda Brtáňa venovanej Bohuslavovi Tablicovi. In: Slovenská literatúra, roč. 66, 2019, č. 5, s. 346-357. ZAPADOV, Alexandr Vasilievič: Poety XVIII veka (M. V. Lomonosov, G. R. Deržavin). Moskva : Izdatel'stvo Moskovskogo universiteta, 1979. ZAVARSKÝ, Svorad: Martin Sentiváni: Dissertatio cosmographica seu De mundi systemate / Sústava sveta. Kozmologická štúdia. In: Slavica Slovaca, roč. 46, 2011, č. 3, s. 3 - 154 .

Mgr. Martin Braxatoris, PhD.

Ústav slovenskej literatúry SAV

Dúbravská cesta 9

84104 Bratislava

Slovenská republika

E-mail: Martin.Braxatoris@savba.sk 